\title{
Retirement: Institutional Pathways and Individual Trajectories in Britain and Germany
}

\author{
by Anette E. Fasang \\ Yale University
}

Sociological Research Online, Volume 15, Issue 2,

$<$ http://uww. socresonline.org.uk/15/2/1.htm/>

$10.5153 /$ sro. 2110

Received: 27 Apr 2009 Accepted: 19 Apr 2010 Published: 30 Apr 2010

\begin{abstract}
Since the 1970s people have retired increasingly early across advanced societies. Parallel to this trend, numerous institutional early retirement pathways evolved, such as bridge unemployment and pre-retirement schemes. This article compares retirement in Britain and Germany to show how individuals progress through these institutional retirement pathways. The analysis uses longitudinal data and recent innovations in sequence analysis to capture the sequential nature of retirement as a series of transitions over time. As expected, prominent institutional retirement pathways are mirrored in individual retirement trajectories. Beyond these expected patterns, there are pronounced regularities in individual retirement trajectories outside of explicit institutional pathways. The 'institution of the family' is an additional powerful force in structuring women's retirement. Access to advantageous institutional retirement pathways is stratified by gender, education, income, and health. The article concludes that specific population groups, particularly women, are systematically excluded from protective institutional early retirement pathways in Britain and Germany.
\end{abstract}

\section{Keywords: Retirement, Aging, Life Course, Sequence Analysis, Germany, Britain, Gender}

\section{Introduction}

1.1 Since the 1970s, the average age of retirement has fallen substantially (Guber \& Wise 1998, Guillemard \& Rein 1993). For instance, between 1970 and 2000 the employment rate of men aged 60 to 64 fell from 74 percent to 30 percent in Germany, and from 81 percent to 47 percent in Britain, while statutory pension age for men remained stable at 65 in both countries (Ebbinghaus 2006: 97). The early retirement trend, defined as a widening gap between statutory pension age and factual average retirement age, peaked in the late 1990s. Economic restructuring, rising unemployment, and labor market uncertainty are put forward as the main driving forces of early retirement (Ebbinghaus 2006, Kohli et al. 1991).

1.2 Parallel to this trend, numerous institutional retirement pathways evolved that facilitated early labor force exit (Ebbinghaus 2006, Kohli et al. 1991, O'Rand \& Henretta 1999). Institutional early retirement pathways facilitated lay-offs of older workers by allowing for prolonged unemployment benefits or various preretirement schemes. Given pressures of economic restructuring and increasing uncertainty on the labor market, this met the interests of employers, social partners, and employees (Blossfeld et al. 2006, Ebbinghaus 2006, Golsch et al. 2006).

1.3 The literature on institutional early retirement pathways has emphasized the sequential nature of retirement as a series of transitions (Ebbinghaus 2006, Kohli et al. 1991, Laczko \& Phillipson 1991). For example, possible transitions in the retirement process are from employment to unemployment to old age pension. Individual level retirement research, however, has mostly either employed static models of retirement outcomes, such as pension income (e.g. Hyde et al. 2004), or used event history methods to model specific transitions in the retirement process, such as the timing of labor force exit (Blossfeld et al 2006). Another line of research has reconstructed 'ideal types' of possible pathways into retirement based on qualitative interview data (Higgs et al. 2003). The gerontological literature on retirement pathways has emphasized how different routes into retirement and a subjective sense of control in this process affect subsequent adjustment and well-being in retirement (Calvo et al. 2009, De Vaus et al. 2007, Marshall et al. 2001, van Solinge \& Henkens 2007).

1.4 Static analyses of retirement and the focus on single transitions have diverted attention from retirement as a sequentially linked process on the individual level. At the same time, the sequential nature of retirement is an important element of institutional retirement pathways (Kohli \& Rein 1991). Numerous scholars have argued that a better incorporation of the sequential nature of retirement is crucial to advance our understanding of retirement (Han \& Moen 1999, O'Rand \& Henretta 1999, Szinovacz 2003). Additional support for this view comes from qualitative research, which suggests that retirement should be studied as a process over time that involves the interplay between structure and agency (Higgs et al. 2003). The focus on single transitions and static retirement outcomes despite the theoretical emphasis on the sequential nature of retirement is related to limitations of the methods that are traditionally applied in retirement research. This paper uses a recent innovation in sequence analysis, Lesnard's dynamic Optimal Matching (OM) distance (Lesnard 2006, 2008), to capture the sequential nature of individual retirement trajectories.

1.5 To examine how pension institutions and institutional retirement pathways play out in individual retirement trajectories, I compare the cohorts born from 1932 to 1940 in Britain and Germany ${ }^{\left[{ }^{[}\right]}$. Britain and Germany are ideal cases for comparison because they represent different prototypical pension systems, particularly during the 1990 s and early 2000 s when the study cohort experienced retirement (Ginn et al. 2007). This comparative design enables us to draw more general conclusions about how institutional configurations and individual choices interact in the formation of retirement patterns. 
1.6 The results show that typical individual retirement trajectories mirror prominent institutional pathways, such as the unemployment and disability pathway. However, there are also pronounced regularities in individual retirement trajectories that are not explicitly shaped by institutional pathways. These include a pattern of discontinuous part-time work, retirement patterns of dependence on a (male) breadwinner in the household, and a pattern of 'muddling through' (Moen \& Roehling 2005) various marginal income sources. Access to advantageous institutional retirement pathways is stratified by gender, health, education, and income. Primarily for women, the 'institution of the family' (Allmendinger et al. 1993, Arber et al. 2003, Daly 2000 , Ginn 2003) is a powerful force in structuring retirement.

1.7 The paper proceeds as follows. First, I introduce the conceptual framework and available institutional retirement pathways in Germany and Britain and discuss the interplay between structure and agency in the formation of retirement patterns. Subsequently, I discuss data and methods, and present the results. The paper concludes with a summary of the results and the implications for future cohorts of retirees.

\section{RETIREMENT: INSTITUTIONAL PATHWAYS AND INDIVIDUAL TRAJECTORIES}

2.1 The subsequent analysis relies on three central concepts: (1) 'institutional retirement pathways', (2) 'individual retirement trajectories', and (3) 'typical retirement patterns'. Institutional retirement pathways are social policies that regulate retirement. Individual retirement trajectories are individual retirement processes over time. Typical retirement patterns refer to groups of individual retirement trajectories that follow a common pattern. I will briefly describe each of them.

2.2 'Institutional retirement pathways' are defined as "[...] an institutional arrangement or - in most cases a combination of different institutional arrangements that are sequentially linked to manage the transition process, that is, the period between exit from work and entry into the normal old-age pension system" (Kohli et al. 1991: 6). They refer to social policies, such as prolonged unemployment benefits for older workers, or pre-retirement schemes.

2.3 'Individual retirement trajectories' are defined as "the sequence of primary income sources within the age bracket during which old age pension entrance is theoretically possible" (Fasang 2010). This age bracket is fixed in national pension regulations that define the age at which people are potentially eligible to enter old age pension. In most countries, it spans a five- to ten-year period around statutory pension age. 'Primary income source' refers to the income source that provides the most income if a person receives income from more than one source at any time. Income sources include various types of employment, state transfers (such as unemployment or disability), and old age pensions provided by the state, employers, or private institutions. A specific case is receiving no personal income at all. Persons who never draw old age pensions can be included by treating the absence of an event, in this case old age pension entrance, as a specific case of the process under study. This is needed to identify non-standard retirement trajectories that are not shaped by institutional retirement pathways.

2.4 'Typical retirement patterns' are groups of individual retirement trajectories that follow a common pattern in terms of the order of income sources and the age at which transitions between income sources occur. They are distinct from institutional retirement pathways because they do not refer to social policies and include regularities in individual retirement trajectories outside of such institutional retirement pathways. They consist of the aggregate of several individual retirement trajectories that follow a common retirement pattern.

2.5 Institutional analyses of early retirement pathways have provided extensive insight into the dissolution of retirement as a one-time transition between employment and old age pension that is universally experienced by the working population (Kohli et al. 1991). They have emphasized the sequential nature of retirement and have stressed the institutionalization of early retirement into various pathways. To complement this institutional perspective, analyses that capture the sequential nature of retirement on the individual level are particularly useful for three reasons: institutional retirement pathways (1) cannot represent the full complexity of individual retirement trajectories, (2) are inherently gender biased because they exclude individuals who do not experience these institutionally designed pathways, and (3) cannot capture the sequential nature of retirement in which individuals may combine different institutional alternatives. I will briefly detail each of these points.

2.6 First, individual retirement trajectories are more complex than any single institutional pathway (O'Rand \& Henretta 1999), and not all individual retirement trajectories are captured in institutional pathways. In fact, retirement trajectories that are not shaped by explicit institutional pathways may be a prime source of cross-national variation in retirement. Such non-standard retirement trajectories can take the form of 'muddling through' (Moen \& Roehling 2005) various income sources in a combination of different institutional options. Individual retirement trajectories that are not shaped by institutional pathways draw attention to the population excluded from institutionally designed bridges between employment and old age pension.

2.7 Second, the analysis of institutional retirement pathways is inherently gender biased because institutional pathways mostly target traditional main-breadwinner careers. For instance, in Germany generous unemployment and pre-retirement pathways negotiated in collective bargaining were primarily open to employees in large companies in the manufacturing and extracting industries (Knuth \& Kalina 2002), which provide jobs in typically male occupations. Similarly, in Britain men have greater occupational pension coverage due to their concentration in large corporations and occupations that provide better fringe benefits (Ginn \& Arber 1993). More generally, all institutional retirement pathways are tied to previous labor force participation and provide more generous benefits with increasing quality and quantity of employment. Since women continue to work less and in lower quality jobs than men, they often lack access to any of these institutional retirement pathways. The 'institution of the family' (Allmendinger et al. 1993, Ginn 2003, Szinovacz et al. 1992) has been largely disregarded as an important additional force in shaping women's retirement trajectories following discontinuous employment careers.

2.8 Third, institutional pathways, while explicitly acknowledging the sequential nature of retirement, do not represent individual retirement trajectories as they evolve over time. Institutional analyses theoretically conceptualize retirement as a sequential process but may miss important dynamics in which individuals 
combine different benefit sources in a series of transitions. Individuals may actively choose from and combine various institutional options available to them (O'Rand \& Henretta 1999). For example, after running out of unemployment benefits, a person may resume employment, or if eligible, enter disability pension or old age pensions, and thereby combine different institutional pathways with moves into and out of employment. After a brief introduction of available institutional retirement pathways in Germany and Britain, I elaborate on the interplay between structure and agency in the emergence of retirement patterns.

\section{Institutional retirement pathways in Germany and Britain}

2.9 Old age pensions in Germany and Britain are anchored in different welfare state traditions (Daly 2000, Esping-Andersen 1990). Germany represents the protectionist conservative welfare regime based on the principle of subsidiarity. Britain is classified as a liberal welfare state that assigns primary responsibility for the provision of welfare to individuals. The pension systems in effect for the study cohort (1932-1940) were at the height of institutional differences throughout the 1990s and early 2000 s when these cohorts retired (Ginn et al. 2007). I focus on an intuitive presentation of the core differences in the German and British pension systems that are relevant for country-specific institutional retirement pathways. For comprehensive overviews of the German and British pension systems see Schulze \& Jochem (2007), Schulze \& Moran (2007), and Ebbinghaus (2006).

2.10 Germany represents the 'Bismarck' model of a pension insurance with generous pay-as-you-go (PAYG) financed state pensions (Schulze \& Jochem 2007). Occupational pensions, while fairly widespread, were the least important source of pension income and accounted for only 7 percent of pension income in 1999. Another 10 percent of pension income came from private pensions, mainly life insurances (Council of the European Union 2003: 32). If they had contributed to the system for at least 5 years, all people in the study cohort had a claim on a public pension when they reached the statutory retirement age of 65 (Börsch-Supan \& Schnabel 1998). The German pension system is based on active life course policies that seek to actively shape life course transitions, such as retirement, through politico-administrative intervention (Fasang 2008, Leisering 2003). Active life course policies in Germany, however, have been directed mainly at male breadwinner life courses. Female life courses were subject to non-state forces to a greater extent, primarily women's family histories (Allmendinger et al. 1993).

2.11 Britain represents the 'Beveridge' pension model, in which occupational and private pensions have a strong tradition and are often essential for living maintenance in old age (Schulze \& Moran 2007). State pensions consist of a flat rate Basic State Pension (BSP) and a supplementary state earnings related pension scheme (SERPS), ${ }^{[2]}$ which are both financed on a PAYG principle. Together, these two pension types are referred to as National Insurance (NI) retirement. Statutory pension age was 65 for men and 60 for women in the study cohort. It was possible to contract out of SERPS into various approved occupational and private pension schemes. This was particularly encouraged after a major retrenchment of state pensions in 1986 that led to a boost in available personal pension schemes (Disney et al. 2004). In British pension policy, the state intentionally avoids active intervention in structuring the life course transition of retirement (Leisering 2003). As a consequence, greater responsibility is placed on individuals to manage the retirement process than in Germany (Golsch et al. 2006, Laczko \& Phillipson 1991).

2.12 These basic differences in the British and German pension systems shaped the development of country-specific institutional retirement pathways throughout the 1990s and early 2000s. In Germany, institutional retirement pathways were driven mainly by the pull factors of protective state benefits (Ebbinghaus 2006), which generated specific 'early entrance routes'. In contrast, in Britain early retirement was driven mainly by push factors of the labor market which generated 'early employment exit routes' rather than institutional early entrance pathways (Laczko \& Phillipson 1991).

2.13 In both countries institutional early retirement pathways for the study cohort fall into three broad categories: (1) unemployment and (2) disability in both countries, (3a) state subsidized pre-retirement schemes in Germany, and (3b) occupational pensions in Britain (Ebbinghaus 2006, Jacobs et al. 1991, Laczko \& Phillipson 1991, O'Rand \& Henretta 1999). ${ }^{[3]}$ Access to these institutional retirement pathways was socially stratified by eligibility conditions tied to resources such as health, occupation, and pension benefits accumulated throughout the life course (Dannefer 2003, Flippen \& Tienda 2000, O'Rand \& Henretta 1999). Institutional retirement pathways further differ in cultural meaning and stigma related to norms about appropriate retirement age (Ebbinghaus 2006, Kohli et al. 1991, Radl 2008). In the following sections, I briefly discuss each of these institutional pathways.

\section{The unemployment pathway}

2.14 In Germany, bridge unemployment was a prominent early entrance route which became known as the '59er-regulation' (Knuth \& Kalina 2002, Teipen \& Kohli 2004). According to this regulation, older workers could exit employment at age 59 and receive unemployment benefits until entering a five-year jobless pension from age 60 to 64 . At age 65 they could then enter normal old age pension. In the late 1980s, longterm unemployment benefits for older workers were extended to 32 months. As a result, the unemployment pathway could begin as early as 57 and four months. Unemployment provided a fairly generous pathway with a replacement rate of 39 percent in 1995 (Ebbinghaus 2006: 132), which was often topped off by additional firm level severance pay. The expansion of the unemployment pathway was negotiated through collective bargaining in response to economic restructuring, increasing skill intensity, and downsizing, primarily in the manufacturing and extraction industries (Knuth \& Kalina 2002).

2.15 In Britain, the unemployment pathway is best described as a long-term social insurance pathway of means-tested minimum benefits after a short period of low unemployment benefits (Laczko \& Phillipson 1991). The 'job seeker's allowance' is a flat-rate unemployment benefit that until 1995 was paid to the unemployed for one year, and after 1995 was paid for only six months (Ebbinghaus 2006: 135). For the study cohort, there were no special prolonged unemployment benefits or jobless pensions for older workers who were laid off. The unemployment pathway in Britain provided a replacement rate of only 17 percent in 1995 (Ebbinghaus 2006: 132), and therefore was far less generous in terms of both benefit level and benefit duration than its German counterpart. After the relatively short period of receiving the 'job seeker's 
allowance', means-tested social assistance (referred to as 'income support') was the only option for unemployed older workers in the study cohort.

\section{The disability pathway}

2.16 Disability benefits are a major early retirement pathway in Germany and Britain (Jacobs et al. 1991, Laczko \& Phillipson 1991). Even if not intended as an explicit pathway for early retirement, disability pensions often were received by people above 50 until they could enter normal old age pensions. In Germany, the disability and unemployment pathways have been discussed as potential substitutes that target a similar population of lower-educated workers who are at higher risk of bad health and unemployment. However, evidence supports individual health as the main reason for claims to disability pensions, while aggregate unemployment is the primary driver of claims to the unemployment pathway (Riphahn 1997), which suggests that they do not function as institutional substitutes. The disability pathway has to be seen in the context of other alternatives. Given the lack of an extensive unemployment pathway in Britain, the disability pathway is the only public program that grants older workers long-term income support for diminished work capacity in old age. Compared to Germany, replacement rates are lower, and eligibility requirements are stricter. In 1995, disability pensions in Germany provided a replacement rate of 44 percent compared to only 28 percent in Britain (Ebbinghaus 2006: 137). In Britain, disability benefits are based on strict medical and earnings tests. In Germany, disability pensions take into account older workers' labor market prospects and consider whether older workers with a certain degree of disability will be able to obtain 'commensurate' employment (ibid.: 140). Nevertheless, other institutional options, such as unemployment or pre-retirement, often are more attractive and less stigmatized than the disability pathway (Jacobs et al. 1991).

\section{The pre-retirement and occupational pension pathways}

2.17 In Germany, numerous institutional early retirement options existed for specific population groups. Pension entrance was possible at age 63 for the long-time insured (35 contribution years). This became known as 'flexible retirement' (Börsch-Supan 2000). During the 1990s, most men retired at age 63 under this flexible retirement scheme (Jacobs et al. 1991). Women could enter old age pension at age 60 . To be eligible for this 'woman's pension', women had to be employed for at least 10 years after age 40 and for at least 15 years in total.

2.18 In addition to these specific early pension entrance regulations, state-subsidized firm-level preretirement schemes were an important retirement pathway in Germany. Powerful unions negotiated these pathways in collective bargaining to ensure cushioned early labor force exit for older workers. Subsidized pre- and partial retirement was introduced in the 1980s and was continuously modified and expanded throughout the 1990s (Teipen \& Kohli 2004). All people in the study cohort could enter old age pension at age 60 following partial retirement (Klammer 2003).

2.19 In contrast to the situation in Germany, state-level pre-retirement schemes did not exist for the study cohort in Britain (Disney et al. 2004). Social policies were strongly work centered with low minimum benefits to encourage employment (Golsch et al. 2006). Employers' willingness to co-finance early exit from work with occupational pensions was crucial to at least partly counterbalance the lack of generous statefinanced early retirement pathways (Ebbinghaus 2006). Occupational and private pensions could be drawn from age 50, albeit usually at high deductions before the state pension age. However, access to occupational pensions was highly selective, which primarily benefited highly-educated employees with full employment histories in large corporations. This particularly hurt women who interrupted their careers for family reasons. In addition, female employment was concentrated in small firms in the private sector that rarely provided occupational pensions (Ginn 2003, Ginn \& Arber 1993; 1996).

\section{Structure and agency in the formation of typical retirement patterns}

2.20 The conceptual framework of institutional retirement pathways, individual retirement trajectories, and typical retirement patterns inherently alludes to the interplay between structure and agency in the formation of typical retirement patterns. Are typical retirement patterns shaped by labor market pressures and available institutional retirement pathways (structure), or do they reflect voluntary early exit and individual choices made across retirement trajectories (agency)? The literature is divided between proponents of a microeconomic view that emphasizes individual choice in retirement (e.g. Gruber \& Wise 1999), and a structural perspective that highlights institutional context and the embeddedness of retirement decisions in family and friendship networks (e.g. Henkens \& Van Dalen 2003, van Solinge \& Henkens 2007). Previous research highlights several restrictive factors on individual choice in retirement: organizational restructuring, the availability of financial offers, opportunities for leisure and self-fulfillment, and social networks (Higgs et al. 2003, van Solinge \& Henkens 2007).

2.21 Typical retirement patterns are a joint outcome of structural incentives and individual behavioral responses to these incentives (Mayer 2005). The devil is in the details when it comes to how structural pressures relate to individual choices in this process. The comparative analysis of Germany and Britain offers some useful insights on the interplay between structure and agency in retirement. National institutional contexts differ in the degree to which they permit individual differences, such as preferences and abilities, to manifest in behavior (Caspi \& Moffitt 1993). Generally, 'strong' or 'structured' situations can be distinguished from 'weak' or 'unstructured' situations (Caspi \& Moffitt 1993, Mischel 1977). The mandatory universal pension system in Germany creates a strong institutional situation that will evoke similar responses from most individuals. Such a strong institutional context will attenuate individual differences and limit space for individual choice. The complex British pension system creates a weak situation because it is difficult to understand and does not generate uniform expectations about retirement. Since the choice of pension plans is largely individualized, individual differences in terms of risk aversion, myopia, and accumulated resources such as education will highly influence pension accumulation and subsequent retirement trajectories. This weak institutional context may also provide more space for individual choice across retirement trajectories. 
2.22 This paper is primarily exploratory in investigating how individuals progress through institutional retirement pathways to identify regularities in retirement trajectories outside of such institutional pathways. Nevertheless, the strong and weak institutional contexts in Germany and Britain imply several expectations for retirement patterns in the two countries. In Germany, protective pull factors of highly regulated state transfers exert a higher degree of institutional control over retirement trajectories than in Britain. This strong institutional situation will generate more standardized retirement patterns in Germany, i.e. individual retirement trajectories within a typical retirement pattern will be very similar to each other. On the other hand, in Britain unregulated push factors from the labor market exert a more immediate impact on late career exits and individual retirement trajectories (Ebbinghaus 2006). This leaves more space for individual choice in navigating the retirement process, which will become manifest in retirement patterns that are less standardized overall, i.e. individual retirement trajectories within typical retirement patterns will be less similar to each other.

\section{DATA AND METHODS}

3.1 I use data for West Germany from the German Socioeconomic Panel (GSOEP) and data for Britain from the British Household Panel Survey (BHPS). ${ }^{[4]}$ They are both ongoing annual household panel data sets. The GSOEP was first fielded in 1984 and the BHPS in 1991. I follow retirement trajectories for each individual for 8 years between ages 58 to 65 , until their $66^{\text {th }}$ birthday. This age bracket covers crucial age markers for pension entrance that lie between age 60 and 65 in both countries. Income information was retrospectively collected for the previous year in each annual panel wave in both data sets. I reconstruct primary income sequences between age 58 and 65 in monthly intervals using income information from 1990-2005, which was reported in the panel waves 1991-2006.

3.2 In both data sets attrition was particularly high in the first follow up wave; 1985 for the GSOEP, 1992 for the BHPS and mostly due to survey related factors and not respondents' characteristics (Gramlich 2008, Jones et al. 2006). Evidence supports that substantive results on socioeconomic outcomes are largely robust to this attrition (Behr et al. 2005, Jones et al. 2006, Kroh 2009). In the GSOEP, I constructed a nearly balanced panel of 715 persons who are observed for at least 7 panel waves out of 8 necessary waves for retirement trajectories from age 58 to 65 . Income information is missing for 6 percent of the months covered by retirement trajectories. Missing income information was forward filled with the last available income information (maximum of 12 consecutive months). Starting in 1994, the GSOEP includes only the number of months in the year the respondent received income from a particular source, but not exactly which months. I reconstruct exact monthly income sequences after 1994 according to a set of rules (see data appendix). In the BHPS 750 persons born between 1932 and 1940 participated in at least 7 panel waves between 1991 and 2006. Income information is missing for 7 percent of the time points and was forward filled with the last available income information.

3.3 Due to the higher complexity of pensions in Britain, different income sources are relevant during retirement trajectories than in Germany. For Germany, I specify eight primary income sources without combinations of different income types since people rarely receive income from several sources at the same time (listed in legend figure 1). ${ }^{[5]}$ In rare cases where a person received income from two sources simultaneously, I consider the income type that provided the higher amount. For Britain, eleven income sources are specified to allow for the combination of state pensions, i.e. National Insurance (NI) retirement, with other pension types (listed in legend figure 2). Simultaneous receipt of NI retirement with occupational or private pensions is frequent, and these income sources often provide income on a similar level.) [6] Differences in relevant income sources are a meaningful cross-country variation and therefore have to be taken into account to identify country-specific typical retirement patterns.

\section{Methods}

3.4 This study uses a combination of sequence analysis and cluster analysis. The most prominent form of sequence analysis in the social sciences is Optimal Matching Analysis (OM) (Abbott 1995, Maclndoe \& Abbott 2004, Martin et al. 2008). The objective of OM is to determine similarity between two sequences by calculating the 'cost' of turning one sequence into another with two types of transformation operations: (1) substitution of a state in a sequence with another and (2) insertion or deletion of a state, referred to as 'indel operations'. The researcher assigns each of these two transformation operations a cost. The total 'costs' of turning one sequence into another determines the distance between two sequences (for a comprehensive introduction see Maclndoe \& Abbott 2004).

3.5 Two major points of criticism of OM address that (a) results may be an artifact of cost assignment that often seems arbitrary, and (b) transformation operations cost the same at each point in time of the process but may mean something very different at the beginning or the end of a process (Wu 2000). This study uses a recent advancement in sequence analysis, Lesnard's dynamic Optimal Matching (OM) distance, that provides a refined account of timing within sequences (Lesnard 2006, 2008). Lesnard's dynamic OM distance is one of several recent technical improvements in sequence analysis, referred to as a 'second wave' of sequence analysis (Aisenbrey \& Fasang 2010). This technique uses only the substitution operations of OM and no indel operations. It has the crucial advantage of calculating data-based, timedependent substitution costs, and thereby avoids arbitrary cost assignment by the researcher. Technically, Lesnard's dynamic OM distance calculates separate substitution cost matrices at each point in time based on the frequency of transition between two states at each time point. As a result, we obtain pair wise distances at each time point that then are summed up to an overall distance. Since substitution costs are fully derived from the data itself, Lesnard's dynamic OM distance is particularly useful for exploratory research.

3.6 Translated to the subsequent analysis of retirement trajectories, Lesnard's dynamic OM distance implies the following: a substitution of employment with old age pension is considered more costly, thus producing more distance, at an age when few persons in the sample transition between employment and old age pension. It is less costly at ages when many people in the sample transition between employment and old age pension. Substitutions of states/income sources thus are 'cheaper' at typical retirement transition peaks. This technique emphasizes age-graded temporal patterning during retirement trajectories 
to determine similarity of retirement sequences. In a second step, a matrix containing Lesnard's dynamic OM distance for each pair of retirement trajectories enters a ward cluster analysis (Ward 1963) to identify clusters of individual retirement trajectories that follow a common pattern. Each of these clusters of similar retirement trajectories represents a typical retirement pattern.

\section{RESULTS: TYPICAL RETIREMENT PATTERNS IN BRITAIN AND GERMANY}

4.1 The results show 7 typical retirement patterns in Germany and 8 typical retirement patterns in Britain. These cluster numbers were determined by applying a 'relative improvement' rule (Aisenbrey \& Fasang 2010). This 'relative improvement rule' is based on comparing ratios of mean within- to mean betweencluster distances for several cluster solutions (see table 1). Lacking conventions for an acceptable ratio of within- to between-cluster distances, Aisenbrey and Fasang (2010) propose that mean within-cluster distance should be at least .5, i.e. half, of mean between-cluster distances to indicate truly distinct groups. A large relative decrease in this ratio when allowing for an additional cluster indicates preferable cluster solutions. For Germany, the relative decrease is largest in the step from a six to seven cluster solution (.110) at which mean within-cluster distances are roughly one-third of mean between-cluster distances (.319) (table 1). For Britain, an eight cluster solution is the best grouping because the decrease of .047 in the step from a seven to eight cluster solution is still considerable, and the ratio falls below the minimum standard of .5 with this step (table 1). The ratio of within- to between-cluster distances is higher for all cluster solutions in Britain, which reflects overall higher within-cluster heterogeneity. As expected, individual retirement trajectories are more heterogeneous and less standardized around specific age markers in Britain than in Germany. In Germany, protective pull factors of highly regulated state transfers exert a higher degree of institutional control over retirement and generate typical retirement patterns of individual retirement trajectories that are very similar to each other. In Britain, unregulated push factors from the labor market and a more complex pension system generate overall less standardized typical retirement patterns, i.e. individual retirement trajectories within typical retirement patterns are less similar to each other.

Table 1 Mean within- and between-cluster distance ratios

\begin{tabular}{|l|c|c|c|c|}
\hline & \multicolumn{2}{|c|}{ Germany } & \multicolumn{2}{c|}{ Britain } \\
\hline Cluster nr. & $\begin{array}{c}\text { mean within } \\
\text { mean between }\end{array}$ & $\begin{array}{c}\Delta \text { within/ } \\
\text { Between }\end{array}$ & $\begin{array}{c}\text { mean within/ } \\
\text { mean between }\end{array}$ & $\begin{array}{l}\Delta \text { within/ } \\
\text { Between }\end{array}$ \\
\hline 2 & .585 & & .790 & .788 \\
\hline 3 & .473 & .112 & .791 & .002 \\
\hline 4 & .409 & .064 & .711 & .080 \\
\hline 5 & .398 & .011 & .629 & .082 \\
\hline 6 & .429 & -.031 & .526 & .103 \\
\hline 7 & .319 & .110 & .479 & .047 \\
\hline 8 & .302 & .017 & .457 & .022 \\
\hline 9 & .281 & .021 & .438 & .019 \\
\hline 10 & .261 & .020 & .493 \\
\hline
\end{tabular}

Note: numbers in bold are the chosen cut-off points for the cluster solutions in Germany and Britain

4.2 Figures 1 and 2 show the clusters that represent typical retirement patterns as sequence index plots (Kohler \& Brzinsky-Fay 2005, Scherer 2001). The $\mathrm{N}$ of cases is displayed on the $\mathrm{y}$-axis, and age is displayed on the $x$-axis. The different color shadings represent different primary income sources. Each horizontal line represents one individual's retirement trajectory. Sequence index plots demonstrate the power of visual representation to convey information about processes that evolve over time. Recurrent states and the orderliness of processes are easily visible. 
Figure 1 Seven typical retirement patterns: Germany
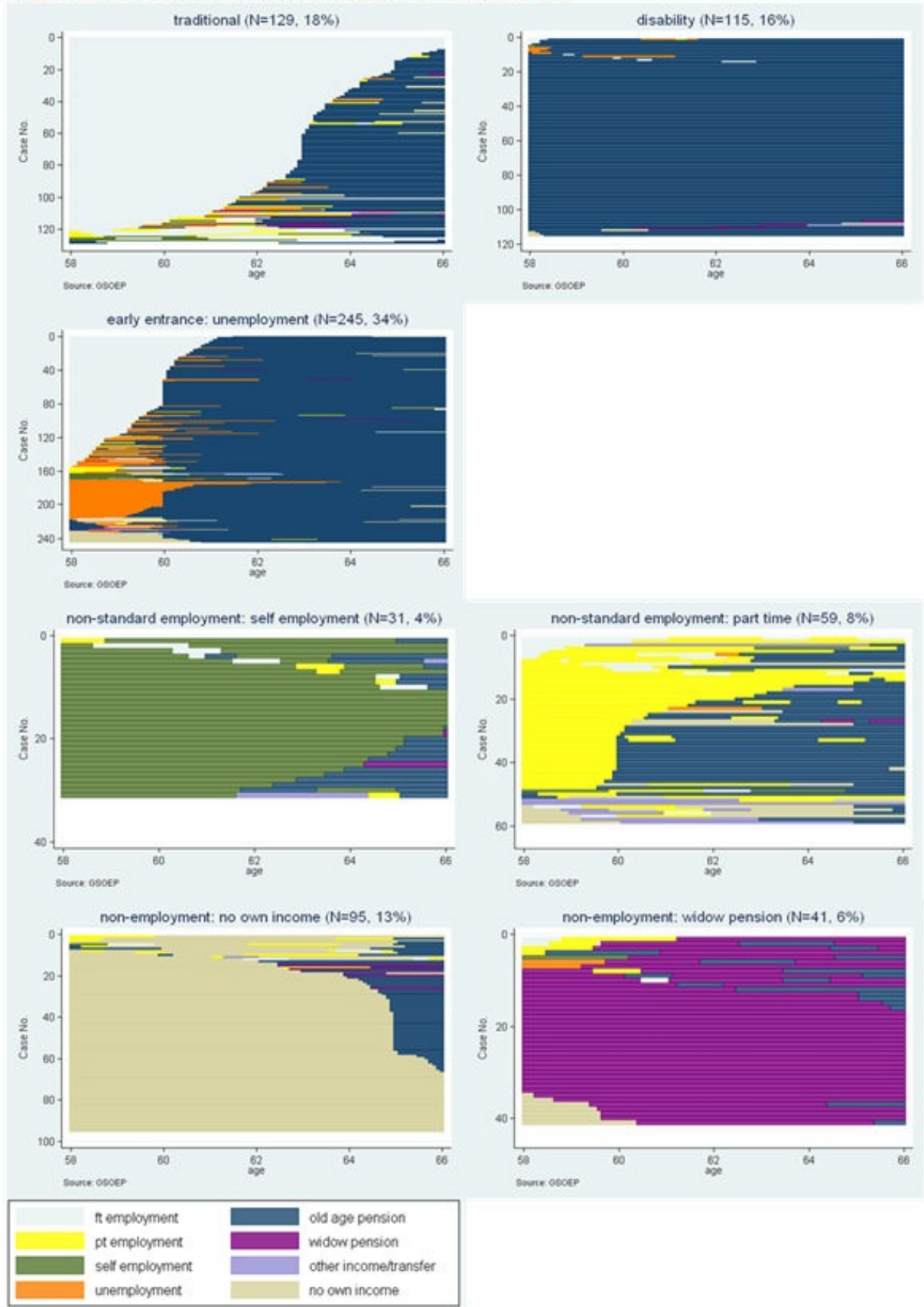

\section{Figure 2 Eight typical retirement patterns: Britain}
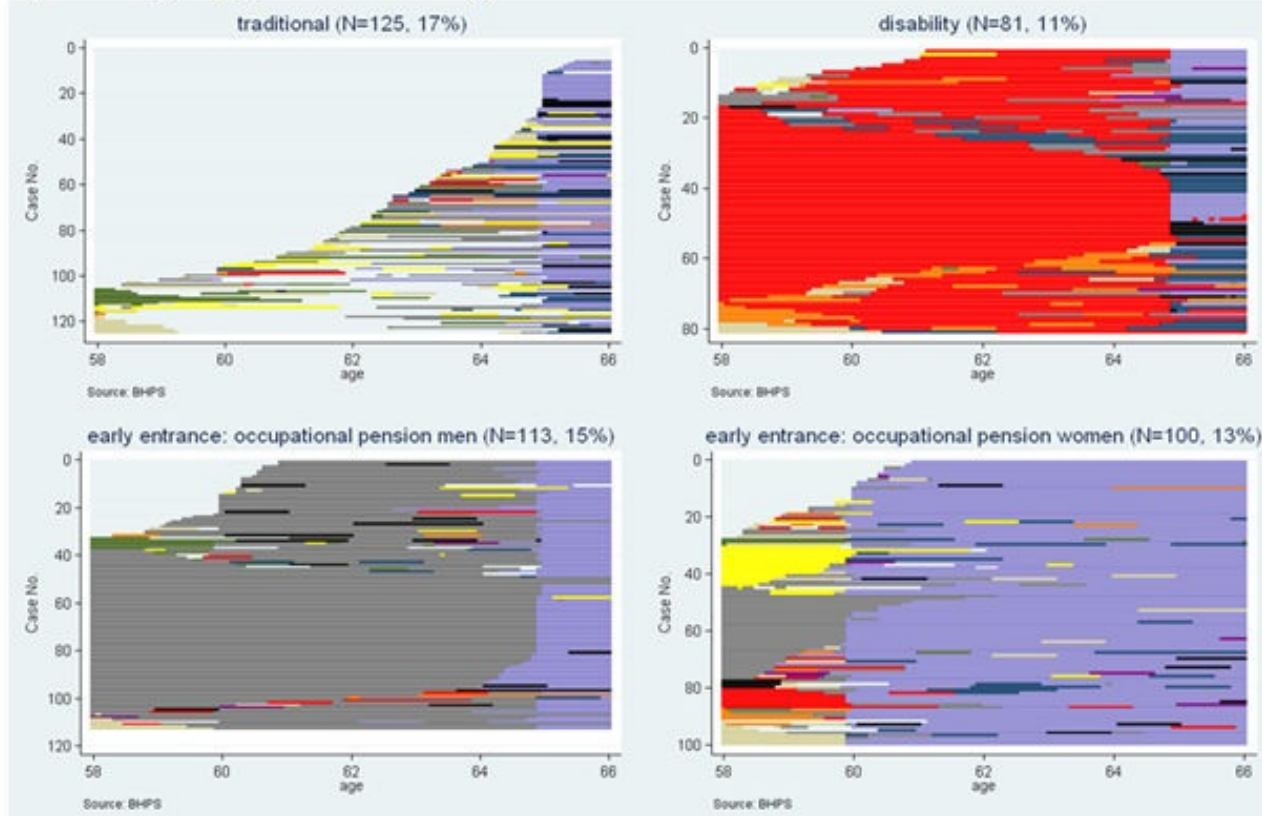


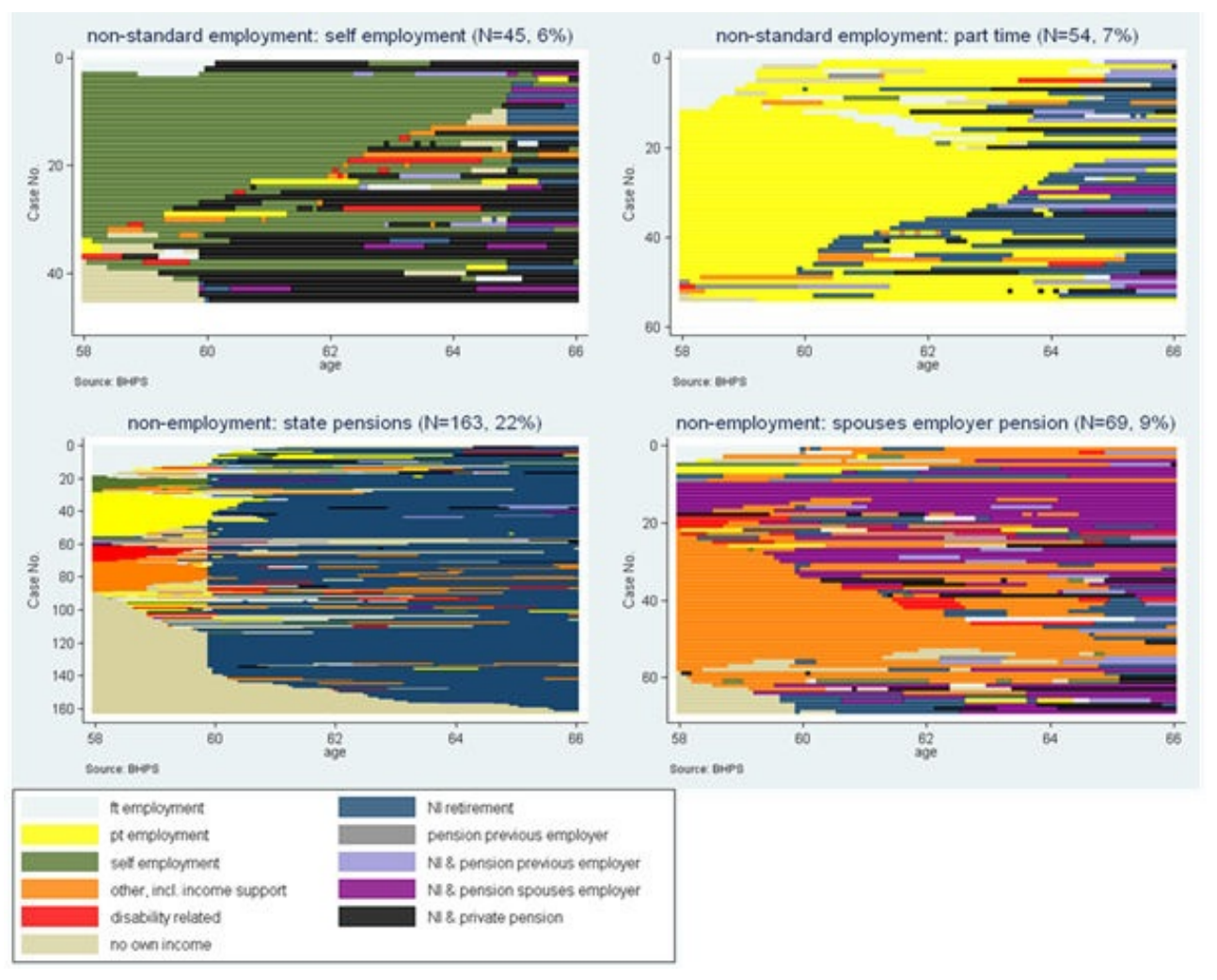

4.3 The clusters of typical retirement patterns can be related to each other as approximate 'cross national pairs' of similar retirement patterns. Table 2 presents an overview of the typical retirement patterns and the distribution of gender and education for each pattern. Figures 3, 4 and 5 show mean subjective health, as well as personal and household income for each cluster. In Britain the self - employment pattern is excluded from the income graphs (4\&5), because income information for the self employed was to incomplete to represent their average income across retirement trajectories.

Table 2 Typical retirement patterns: overview

\begin{tabular}{|c|c|c|c|c|c|}
\hline Germany & & & Britain & & \\
\hline Retirement pattern & $\begin{array}{c}\% \\
\text { female }\end{array}$ & $\begin{array}{l}\text { \% higher } \\
\text { education }\end{array}$ & Retirement pattern & $\begin{array}{c}\% \\
\text { female }\end{array}$ & $\begin{array}{l}\% \text { higher } \\
\text { education }\end{array}$ \\
\hline
\end{tabular}

(1) traditional

\begin{tabular}{llllll}
\hline full-time employment & 17 & 47 & full-time employment & 23 & 25 \\
\hline & & & & & \\
(2) early entrance & 41 & 22 & $\begin{array}{l}\text { transitional occupational pension/male } \\
\text { transitional occupational pension/female }\end{array}$ & $\begin{array}{c}5 \\
99\end{array}$ & 41 \\
\hline unemployment/pre-retirement & & & 28
\end{tabular}

(3) disability

\begin{tabular}{llllll}
\hline disability & 41 & 21 & disability & 14 & 9 \\
\hline
\end{tabular}

(4) non-standard employment

\begin{tabular}{lcclcc}
\hline self-employment & 29 & 50 & self-employment & 20 & 20 \\
part-time employment & 85 & 18 & part-time employment & 85 & 13 \\
\hline & & & & & \\
(5) non-employment & & & & & \\
\hline widow pension & 100 & 17 & spouse's previous employers pension & 68 & 7 \\
no own income until state pension age & 98 & 24 & entrance at state pension age & 93 & 9 \\
\hline
\end{tabular}

Note: Percent in higher education denotes people with more than basic education, >A level in Britain, >intermediary in Germany

4.4 In both countries, there are five basic types of retirement patterns. Three of these reflect either the traditional retirement pathway intended by the national pension systems or specific institutional early retirement pathways (Kohli \& Rein 1991): (1) a traditional retirement pattern, (2) early entrance patterns (pre-retirement and occupational pensions), and (3) a disability pattern. The remaining two typical retirement patterns display regularities in retirement trajectories that are not explicitly shaped by institutional retirement pathways: (4) retirement through non-standard employment, and (5) retirement patterns characterized by no income from employment (table 2). Below, I first discuss the retirement patterns that reflect institutional retirement pathways followed by a presentation of typical retirement patterns outside of institutional retirement pathways to show how specific population groups, particularly women, are systematically excluded from advantageous institutional retirement pathways. 
4.5 The traditional retirement pattern most closely approximates the 'ideal retirement trajectory' intended by the national pension systems (top left in figure 1\&2). It is represented by only 18 percent in Germany and 17 percent of the study cohort in Britain. In Germany, this group shows the latest full time employment and is characterized by a mostly seamless transition to old age pension. Age 63 is the most common pension entrance age, which is in line with the 'flexible retirement' scheme for the long-time insured. This reflects the normative character of early pension entrance before the statutory pension age of 65 in Germany during the 1990s and early 2000s. In Britain, the traditional retirement pattern shows late full time employment with frequent short-term interruptions before entrance to state and occupational pensions. In both countries, this pattern represents retirement of highly educated men (table 4) in above average health (figure 3), who have the highest mean personal and household income in the respective country comparisons (figures $4 \& 5$ ).

\section{Figure 3 Retirement patterns and subjective health}

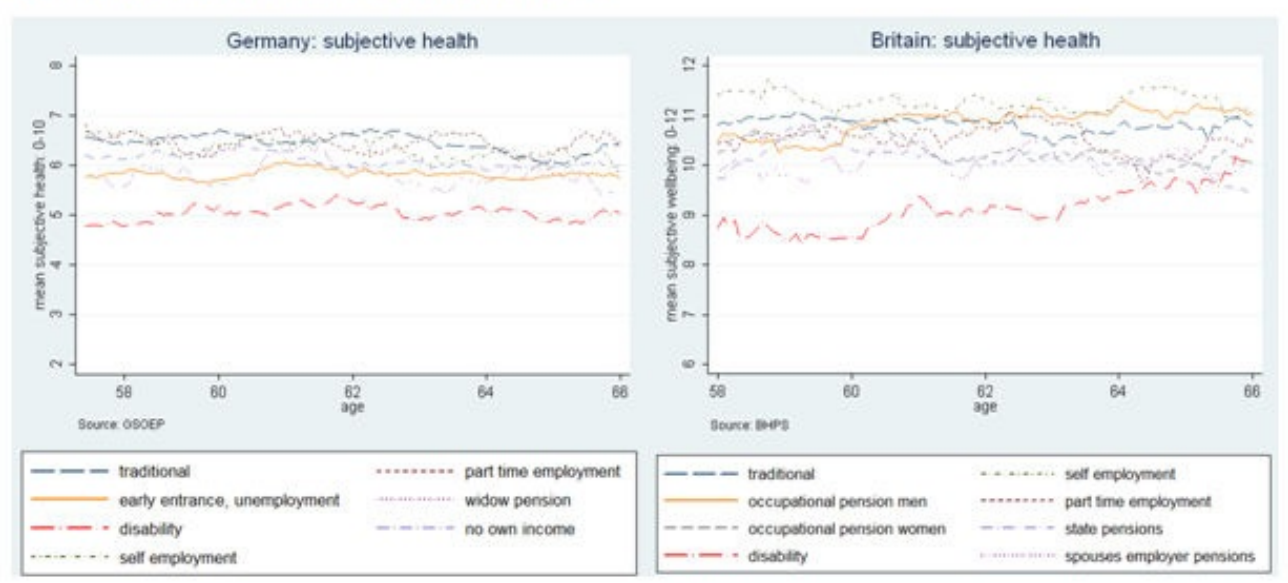

4.6 Early entrance patterns mark early employment exit routes, shaped by the unemployment and preretirement pathway in Germany and by the occupational pension pathway in Britain (figure 1\&2). In Germany, this retirement pattern is roughly twice as common as the traditional retirement pattern (34 percent), which underlines the prevalence of early exit through institutional retirement pathways for the study cohort. In Germany, this retirement pattern demonstrates the socially acceptable externalization of low- to medium-educated older workers who are cushioned by generous unemployment benefits and preretirement programs (table 2, figures $4 \& 5$ ). They enter old age pension at age 60 , either in a direct transition from employment in line with firm level pre-retirement incentives or via unemployment benefits enabled by the '59er-regulation'.) ${ }^{[7]}$

4.7 In Britain, the gender difference in the statutory retirement age of 60 for women and 65 for men generates distinct male and female occupational pension patterns. Together, the male and female occupational pension patterns in Britain represent 28 percent of the sample. For men, this pattern leads through occupational pensions until they enter combined state and occupational pensions at age 65 . Given that they are on average highly educated and in the upper income range, it seems that men with access to occupational pensions can realize financially secured early labor force exit. The female occupational pension pattern includes women who enter combined state and occupational pensions at age 60 through transitional occupational pensions or directly from employment. These women have low personal income but relatively high household income (figure 4\&5). The personal income gap of the male and female occupational pension pattern shows women's disadvantage not only in the extent of occupational pension coverage, but also in the level of occupational pension benefits they hold (Ginn 2003, Ginn \& Arber 1993).

Figure 4 Retirement patterns and personal income

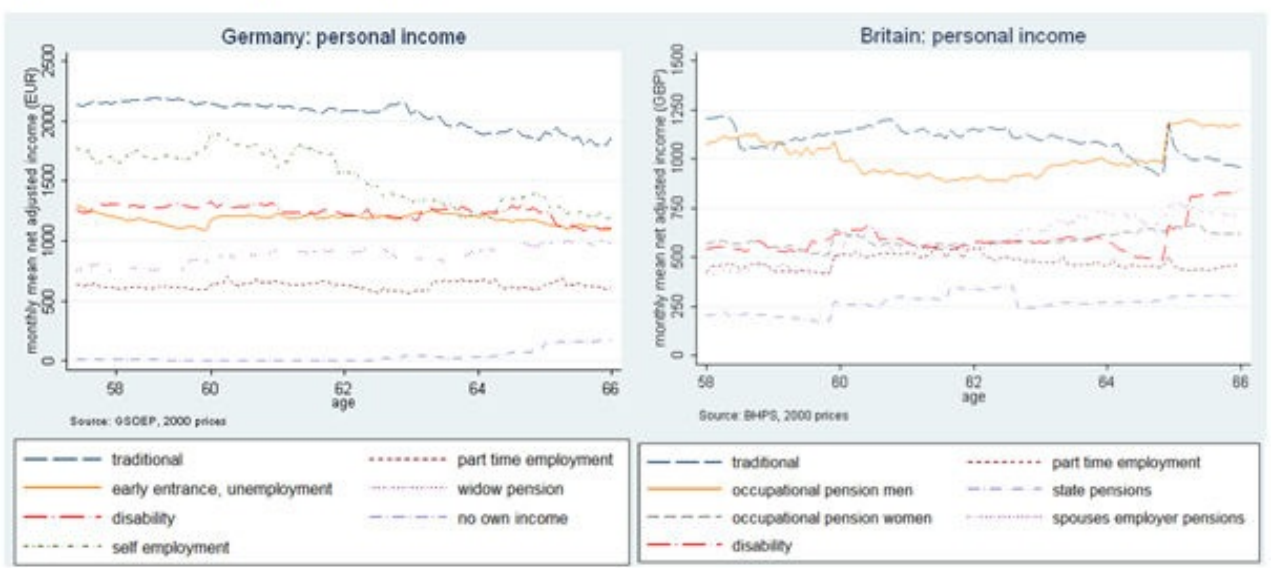




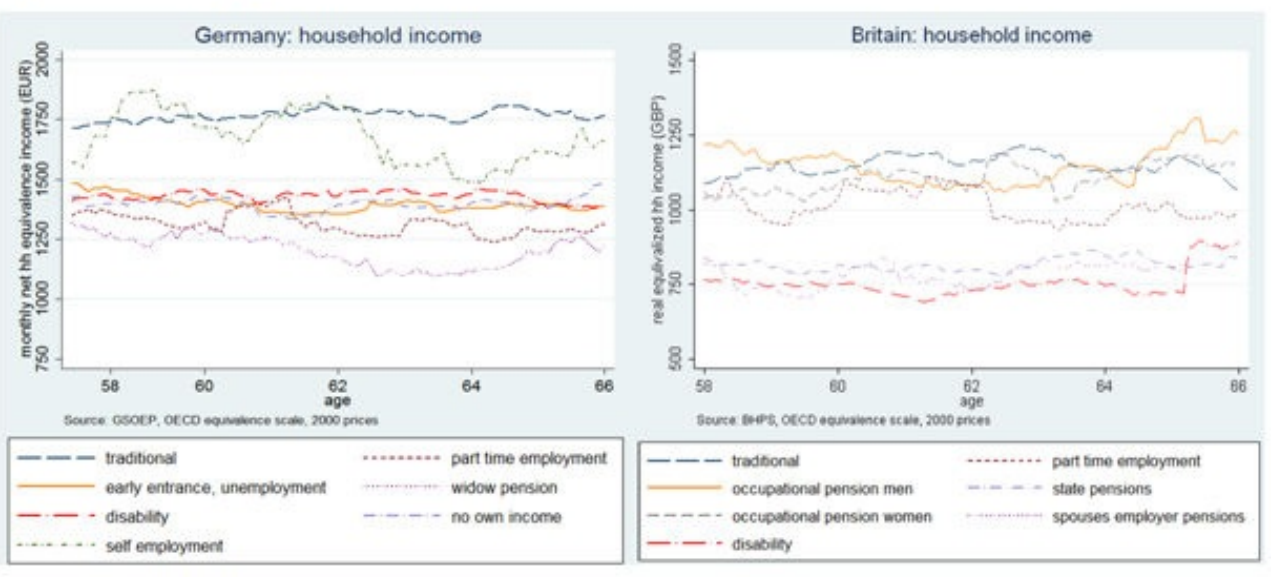

4.8 The disability patterns in both countries consistently show the lowest subjective health ratings (figure 3). They are the individual counterpart of the institutional disability pathways (Jacobs et al. 1991, Laczko \& Phillipson 1991). Although income from disability and old age pensions cannot be unambiguously separated in the GSOEP, the data strongly suggest that this group in Germany is the cross-national equivalent of the British disability pattern, given that pension entrance at this early age would be impossible if not for health related reasons. Disability is a viable early exit route for lower educated men in both countries (table 2), which reflects the accumulation of inequalities in terms of higher health risks for the lower educated over the life course. In line with more generous disability benefits in Germany, household income for the disability pattern is in the middle range in Germany and at the lower end in Britain.

\section{Typical retirement patterns outside of institutional retirement pathways}

4.9 Beyond these three typical retirement patterns shaped by institutional retirement pathways the remaining clusters indicate pronounced regularities in retirement patterns that fall outside institutionally designed pathways. They fall into two groups: retirement patterns of non-standard employment (part-time and self-employment) and retirement patterns in which employment plays no role. Particularly the latter reflects a population that is excluded from institutionally designed pathways and often overlooked in retirement research.

4.10 In both countries there are non-standard employment patterns into retirement that lead through selfemployment or part-time employment before pension entrance and represent 4-8 percent of the national samples (figure 1\&2). Self-employment is a predominantly male pattern. The self-employed in Germany mostly enter old age pension seamlessly at age 63 or 65 . In Britain, pension entrance of the self-employed is fuzzy, showing high age variation, frequent intermediate income sources, and a high prevalence of private pensions. Part-time employment is largely held by women in both countries. In Germany, pension entrance after part-time employment is standardized around age 60 , the eligibility age for the woman's pension option. In contrast, in the British part-time employment pattern transitions to state pensions are fuzzy and temporary with recurrent phases of part-time employment beyond age 60 . Women in the part-time employment pattern are relatively highly educated (table 2 ) but have low personal income (figure 4). In Germany, financial needs of the household seem to be a major motivation for female part-time work, since household income for this pattern is at the lower end (figure 5). In Britain, household income of the part-time employment pattern is in the upper range (figure 5). Apparently, female part-time employment is not only financially motivated. Possibly these women prefer joint retirement with a partner still employed and continue to work part-time until their husbands retire (Arber et al. 2003, Henretta et al. 1993).

4.11 There are two types of non-employment retirement patterns. Most of these retirement patterns are close to 100 percent female (table 2). For these retirement patterns, employment plays no role as a primary income source. As a result they are characterized by some form of dependence: either on a husband (dead or alive) and the state. The first group (bottom left in figure 1\&2) demonstrates the typical retirement pattern for female homemakers. They have very low personal income before entering state pension at statutory pension age for women: 65 in Germany and 60 in Britain. $)^{[8]}$ In both countries, this pattern is associated with the lowest personal income and therefore dependence on a male breadwinner in old age. The household plays an important role in protecting these women from poverty, particularly in Germany (figures 4\&5).

4.12 The second retirement pattern for which employment plays no role is characterized by pensions explicitly derived through a spouse (bottom right in figure 1\&2). In Germany, active pension policies shape a stable pattern of state survivor pensions for widows. In Britain, passive pension policies generate a highly unstable pattern of 'muddling through' (Moen \& Roehling 2005) various income sources and relying on pensions from a spouse's previous employer. Income support is also frequent in this pattern, which marks the closest individual counterpart to the institutional 'unemployment/long-term social assistance' pathway in Britain. The non-employment retirement patterns are associated with low education, and the lowest mean household income in the respective country comparison.

\section{Summary of results}

4.13 The results show that prominent institutional pathways shape regularities in individual retirement trajectories. Disability is a typical retirement pattern in both countries, unemployment and pre-retirement are prevalent patterns in Germany, and early entrance through occupational pensions is an important retirement pattern in Britain. In addition, there are pronounced regularities in typical retirement patterns 
4.14 As expected, typical retirement patterns are overall more de-standardized, i.e. internally less similar, in Britain than in Germany. Besides this difference, typical retirement patterns divide the study cohort into similar socio-demographic groups in Germany and Britain. While access to advantageous institutional retirement pathways is stratified across similar lines of gender, education, income, and health in both countries their temporal patterning is country specific. This is visible, for instance, in the more stable and standardized part-time and self-employment patterns in Germany compared to their unstable and less standardized counterparts in Britain (see figures 1\&2).

4.15 Similar gender policies in otherwise highly distinct pension systems generate typical retirement patterns that are gendered in a similar way in both countries (Daly 2000, Ginn 2003, Orloff 1993). In both countries, the traditional retirement pattern and retirement patterns shaped by the institutional pathways of pre-retirement, occupational pensions, and disability are effectively male. This mirrors the normative modeling of welfare institutions on the work-centered normal life course of a main breadwinner. In such an arrangement, women are channeled into retirement trajectories that are shaped by part-time employment, widowhood, and no personal income as a consequence of the secondary role of their employment in the study cohort (Blossfeld \& Hakim 1997, Meyer \& Pfau-Effinger 2006). Women's retirement trajectories are essentially shaped by the 'institution of the family' (Allmendinger et al. 1993), leading to regularities in typical retirement patterns outside of institutional retirement pathways.

4.16 In Germany, where the welfare state is based on the principle of subsidiarity in nuclear families (Esping-Andersen 1990), household income largely compensates for low personal income associated with typical female retirement patterns (figure 4\&5). This model of subsidiarity has adverse effects for unmarried women, which becomes evident in the low household income associated with the widow pension pattern. In Britain, the dual system of market-based and state pensions divides retirees into a dual structure of highand low-income households: at the upper end there are three retirement patterns with access to occupational pensions and the part-time employment pattern, while the four remaining retirement patterns are at the lower end. Contrary to the compensation of low personal income of typical female retirement patterns within households in Germany, in Britain household contexts actually accentuate overall inequality in a dual structure of high- and low-income households across retirement. This dual structure of high- and low-income households depends on at least one household member having access to occupational and private pensions (Fasang 2008). Assortative mating may further contribute to this dualism of high- and lowincome households throughout retirement in Britain (Blau 1998).

\section{CONCLUSION}

5.1 Numerous scholars have discussed institutional retirement pathways as a key piece in the puzzle of early retirement despite increasing life expectancies in the past decades (Ebbinghaus 2006, Kohli et al. 1991, O'Rand \& Henretta 1999). To show how individuals progress through these institutional pathways, this paper examined typical individual retirement patterns as they evolved over time. This dynamic individual-level perspective highlighted much neglected regularities in non-standard retirement trajectories that are not shaped by explicit institutional pathways. Shifting the focus to such non-standard retirement trajectories demonstrates how access to advantageous institutional retirement pathways is stratified by gender, education, income, and health.

5.2 The results underline the 'institution of the family' as a powerful force in shaping typical female retirement patterns. With the exception of the British female occupational pension trajectory, economic dependence is characteristic for all female retirement patterns. This economic dependence takes several forms: dependence on a male breadwinner in the household, dependence on survivor pensions derived through a former spouse, and dependence on means-tested state benefits in a pattern of 'muddling through' different income sources. The fact that these gendered retirement patterns emerged so clearly in an exploratory analysis forcefully underlines that retirement is a vastly different experience for men and women in the study cohort as a result of their highly gendered life courses (Allmendinger et al. 1993, Arber et al. 2003, Ginn 2003). Increasing gender equality across younger cohorts' working lives will certainly reduce this striking gender divide in retirement patterns. However, even though women have made substantial inroads in the labor market, occupational gender segregation is a particularly persistent component of gender inequality (Charles \& Grusky 2004). The present analysis underlines that occupational gender segregation has been pivotal in the exclusion of women from advantageous institutional retirement pathways. Given the retrenchment of state financed institutional retirement pathways, occupational pensions are gaining importance and they continue to be concentrated in traditionally male occupations and to overvalue typically male employment profiles of uninterrupted full time work over the life course (Ginn 2003, Ginn \& Arber 1993, 1996).

5.3 The analysis has several limitations. Data limitations inhibited a more fine-grained distinction of pension types. It would have been desirable to further distinguish between different types of occupational pensions and between Basic State Pensions and SERPS in Britain and between different pre-retirement schemes and disability pensions in Germany. Similarly, it was not possible to reconstruct longer retirement trajectories (for instance starting at age 55 until 67) given the available observation window in the data and the relatively high data requirements needed to construct these uninterrupted retirement trajectories.

5.4 The results raise many questions for future research. Exactly which accumulated life course resources determine the likelihood of experiencing one of these typical individual retirement patterns? How do the retirement patterns correlate with subsequent mortality, retirement adjustment, life satisfaction, and economic well-being? How do institutional incentives and individual choices play together in the formation of typical retirement patterns? How should and can access to different institutional retirement pathways be regulated?

5.5 How does the present analysis of cohorts that retired in the 1990 s and early 2000 s speak to the situation of current retirees? The comparison of the prototypical 'Bismarck' and 'Beveridge' pension systems in Germany and Britain during this time allows several general conclusions that are valid for other cohorts: weak institutional contexts, like those found in Britain, generate less standardized retirement patterns, i.e. 
retirement trajectories within one retirement pattern are less similar to each other than in strong institutional contexts, like those found in Germany. With a recent retrenchment of the protectionist elements in the German pension system, i.e. the unemployment, pre-retirement and disability pathways (Ginn et al. 2007, Schulze \& Jochem 2007), typical retirement patterns of current retirees are bound to become more heterogeneous in Germany, similar to the situation in Britain during the 1990s and early 2000s.

5.6 Two structural forces create a very different context for current and future retirees than for the study cohort: the financial crisis and population aging. The financial crisis jeopardizes state funded, occupational, and private pensions for current retirees and may lead to a massive increase in retirement patterns that are not shaped by such institutional pathways. For instance, this study demonstrated how in Britain occupational pensions are the most stable and secure retirement pattern for both men and women and highlights the potentially severe consequences of a crisis-related breakdown of occupational pension funds. In Germany, a recent retrenchment in state pensions, along with shutting down the pre-retirement and unemployment pathways (Ginn et al. 2007), suggests that 'muddling through' various means tested income sources will emerge as a distinct retirement pattern for future cohorts of retirees. This trend could be intensified in both countries by the recession and rising unemployment in the wake of the financial crisis.

5.7 Especially in Germany, institutional retirement pathways evolved as a convenient strategy to cushion the social consequences of a decreasing labor demand for older workers. A decreasing demand for older workers has been driven by both a mismatch between older workers qualifications and required job skills (Schömann 2006), and older workers heightened economic vulnerability in times of economic downturn and recession (Blossfeld et al. 2006). There has been a heated debate about population aging as a countervailing force that may increase the demand for older workers given a lack of labor market entrants (Neugart \& Schömann 2002). While an aging workforce will certainly be consequential in the mid- and longterm, in light of the current recession there are no signs of an increasing labor demand for the cohorts that are currently approaching retirement. The financial crisis and recession put social policymakers in a double bind in which older workers face a higher risk of losing their jobs while financial pressures inhibit the maintenance of protective institutionalized early retirement pathways. This structural conundrum will likely spur regularities in retirement trajectories outside of explicit institutional pathways for current and future cohorts of retirees.

\section{Appendix}

\section{Income information in the GSOEP}

Detailed monthly income information is only available in the GSOEP until 1994. After 1994 only the number of months per year that income from a certain source was received is recorded, but which months during the year is not. Information on the amount of income is available across all waves. The following rules are applied to make income information after 1994 more precise. The order in which these rules were applied is important:

- if income from source $x$ was received for 12 month in year $y$, set every month of year $y$ as received income from $x$

- if income from source $x$ was received for $<12$ months in year $y$, but income from source $x$ was received for 12 months in an adjacent year $\left(y_{t-1}\right.$ or $\left.y_{t+1}\right)$, append the number of months received income from $x$ in $y$ to the adjacent year in which income from $x$ was received for 12 months

- if income from source $x$ was received for $<12$ months in year $y$, and income from $x$ was received for 12 months in $y_{t-1}$ and $y_{t+1}$, randomly append the number of months $x$ was received in $y$ to either $y_{t-1}$ or $y_{t+1}$

- if income from $x$ was received for $<12$ months in $y$, but not for 12 month in $y_{t-1}$ or $y_{t+1}$, and there are remaining months of no income source information in $y$, fill in the time spans for which no other income source information is available with the number of months income from $x$ was received

- if income from $x$ was received for $<12$ months in $y$, but not for 12 month in $y_{t-1}$ or $y_{t+1}$ and there are NO remaining months of no income information in $y$, randomly distribute the number of months income from $x$ was received as an additional source of income

\section{Acknowledgements}

I am indebted to Silke Aisenbrey for many insightful discussions and continuous support since the first steps of this research. I thank Karl Ulrich Mayer and Scott Boorman for extended commentaries at various stages of the manuscript. I thank Hilke Brockmann, Hannah Brückner, Tim F. Liao, Sebastian Schnettler, Klaus Schömann and two anonymous reviewers for helpful suggestions. The paper greatly benefited from comments of the participants of the CIQLE workshop at Yale University.

\section{References}

ABBOTT, Andrew. 1995. "Sequence analysis: new methods for old ideas " Annual Review of Sociology 21:93-113.

AISENBREY, Silke, and Anette E. Fasang. 2010. "New Life for Old Ideas: The 'Second Wave' of Sequence Analysis. Bringing the 'Course' Back into the Life Course." Sociological Methods \& Research 38:420-462.

ALLMENDINGER, Jutta, Hannah Brückner, and Erika Brückner. 1993. "The production of gender disparities over the life course and their effects in old age: results from the West German life history study." in Age, Work, and Social Security, edited by A.B. Atkinson, and Martin H. Rein. St. Martin's. 
Ginn. Open University Press.

BEHR, Andreas, Egon Bellgardt, and Urich Rendtel. 2005. "Extent and Determinants of Panel Attrition in the European Community Household Panel." European Sociological Review 21:489-512.

BLAU, David M. 1998. "Labor Force Dynamics of Older Married Couples." Journal of Labor Economics 16 (3):595-629

BLOSSFELD, Hans-Peter, Sandra Buchholz, and Dirk Hofäcker. 2006. Globalization, Uncertainty and Late Careers in Society. Routledge.

BLOSSFELD, Hans-Peter, and Catherine Hakim (eds.). 1997. Between Equalization and Marginalization. Women Working Part-Time in Europe and the United States of America. Oxford University Press.

BÖRSCH-SUPAN, Axel. 2000. "A Model Under Siege: A Case Study of the German Retirement Insurance System." The Economic Journal 110 F24-F45

BÖRSCH-SUPAN, Axel, and Reinhold Schnabel. 1998. "Social Security and Declining Labor-Force Participation in Germany." The American Economic Review 88 (2):173-178

CALVO, Esteban, Kelly Haverstick, and Steven A. Sass. 2009. "Gradual Retirement, Sense of Control, and Retirees' Happiness." Research on Aging 31:112-135. [doi:10.1177/0164027508324704]

CASPI, Avshalom, and Terrie E. Moffitt. 1993. "When Do Individual Differences Matter? A Paradoxical Theory of Personality Coherence." Psychological Inquiry 4:247-271.

CHARLES, Maria, and David B. Grusky. 2004. Occupational Ghettos: The Worldwide Segregation of Women and Men. Stanford University Press.

COUNCIL OF THE EUROPEAN UNION. 2003. "Joint Report by the Commission and the Council on Adequate and Sustainable Pensions. Report 6527/2/03." EU.

DALY, Mary. 2000. The Gender Division of Welfare. The Impact of the British and German Welfare States. Cambridge University Press.

DANNEFER, Dale. 2003. "Cumulative Advantage/Disadvantage and the Life Course: Cross-fertilizing Age and Social Science Theory." Journal of Gerontology: SOCIAL SCIENCES 58B:S327-S337.

DE VAUS, David, Yvonne Wells, Hal Kendig, and Susan Quine. 2007. "Does gradual retirement have better outcomes than abrupt retirement? Results from an Australian panel study." Ageing and Society 27:667682.

DISNEY, Richard, Carl Emmerson, and Sara Smith. 2004. "Pension Reform and Economic Performance in Britain in the 1980s and 1990s." in Seeking a Premier Economy: The Economic Effects of British Economic Reforms, 1980-2000, edited by David Card, Richard Blundell, and Richard B. Freeman. University of Chicago Press.

EBBINGHAUS, Bernhard. 2006. Reforming Early Retirement in Europe, Japan and the USA . Oxford University Press.

ESPING-ANDERSEN, Gosta 1990. "The Three Worlds of Welfare Capitalism." Blackwell Publishing.

FASANG, Anette E. 2008. Family Biographies and Retirement Processes. A Comparative Analysis of West Germany and the United Kingdom, Doctoral Thesis. Jacobs University Bremen.

FASANG. 2010. "Social Policy and Retirement Patterns." Social Forces, submitted for invited resubmission.

FLIPPEN, Chenoa, and Marta Tienda. 2000. "Pathways to Retirement: Patterns of Labor Force Participation and Labor Market Exit Among the Pre-Retirement Population by Race, Hispanic Origin, and Sex." Journal of Gerontology: SOCIAL SCIENCES 55B:S14-S27.

GINN, Jay. 2003. Gender, Pensions and the Lifecourse. How pensions need to adapt to changing family forms. The Policy Press.

GINN, Jay, and Sara Arber. 1993. "Pension Penalties: The Gendered Division of Occupational Welfare." Work, Employment \& Society 7(1):47-70.

GINN, Jay, and Sara Arber. 1996. "Patterns of Employment, Gender and Pensions: The Effect of Work History on Older Women's Non-State Pensions." Work, Employment \& Society 10(3):469-490.

GINN, Jay, Uwe Fachinger, and Winfried Schmähl. 2007. "Reformen der Alterssicherung und der sozioökonomische Status Älterer in Großbritannien und Deutschland [Pension reform and the socioeconomic status of older people in Britain and Germany]." ZeS-Arbeitspapier. Zentrum für Sozialpolitik Bremen 4/2007.

GOLSCH, Katrin, David Haardt, and Stephen P. Jenkins. 2006. "Late careers and career exits in Britain." in Globalization, Uncertainty and Late Careers in Society, edited by Hans-Peter Blossfeld, Sandra Buchholz, and Dirk Hofäcker. Routledge.

GRAMLICH, Tobias. 2008. Analyse der Panelausfälle im Sozio-oekonomischen Panel SOEP. DIW Discussion Paper No. 129.

GRUBER, Jonathan, and David A. Wise (eds.). 1999. Social Security and Retirement around the World . University of Chicago Press. 
GUBER, Jonathan, and David Wise. 1998. "Social Security and Retirement: An International Comparison." The American Economic Review 88 (2):158-163

GUILLEMARD, Anne-Marie, and Martin Rein. 1993. "Comparative Patterns of Retirement: Recent Trends in Developed Societies." Annual Review of Sociology 19:469-503. [doi:10.1146/annurev.so.19.080193.002345]

HAISKEN-DENEW, John P. , and Joachim R Frick (eds.). 2005. Desktop Companion to the German SocioEconomic Panel Study (SOEP). German Institute for Economic Research (DIW).

HAN, Shin-Kap, and Phyllis Moen. 1999. "Clocking Out: Temporal Patterning of Retirement." American Journal of Sociology 105(1):191-236. [doi:10.1086/210271]

HENKENS, Kene, and Hendrik P. Van Dalen. 2003. "Early Retirement Systems and Behavior in an International Perspective." in Retirement. Reasons, Processes and Results, edited by Gary A. Adams, and Terry A. Beehr. Springer.

HENRETTA, John C., Angela M. O'Rand, and Christopher G. Chan. 1993. "Joint Role Investments and Synchronization of Retirement: A sequential Approach to Couples' Retirement Timing." Social Forces 71 (4):981-1000 [doi: $10.2307 / 2580127]$

HIGGS, Paul, Gill Mein, Jane Ferrie, Martin Hyde, and James Nazroo. 2003. "Pathways to early retirement: structure and agency in decision-makin among British civil servants." Ageing and Society 23:761-778. [doi:10.1017/S0144686X03001326]

HYDE, Martin, Jane Ferrie, Paul Higgs, Gill Mein, and James Nazroo. 2004. "The effects of pre-retirement factors and retirement route on circumstances in retirement: findings from the Whitehall II study." Ageing and Society 24:279-296. [doi:10.1017/S0144686X03001624]

JACOBS, Klaus, Martin Kohli, and Martin Rein. 1991. "Germany: The diversity of pathways." in Time for Retirement. Comparative Studies of Early Exit from the Labor Force, edited by Martin Kohli, Martin Rein, Anne-Marie Guillemard, and Herman van Gunsteren. Cambridge University Press.

JONES, Andrew M. , Xander Koolman, and Nigel Rice. 2006. "Health-related non-response in the British Household Panel Survey and European Community Household Panel: using inverse-probability-weighted estimators in non-linear models." Journal of the Royal Statistical Society A 169(3):543-569.

KLAMMER, Ute. 2003. "Altersteilzeit zwischen betrieblicher und staatlicher Sozialpolitik." Sozialer Fortschritt 2:39-47.

KNUTH, Matthias, and Thorsten Kalina. 2002. "Early Exit from the Labour Force between Exclusion and Privilege." European Societies 4:393-418.

KOHLER, Ulrich, and Christian Brzinsky-Fay. 2005. "Stata Tip 25: Sequence Index Plots." The Stata Journal 5(4):601-602.

KOHLI, Martin, and Martin Rein. 1991. "The changing balance of work and retirement." Pp. 1-35 in Time for Retirement. Comparative Studies of Early Exit from the Labor Force, edited by Martin Kohli, Martin Rein, Anne-Marie Guillemard, and Herman van Gunsteren. Cambridge University Press.

KOHLI, Martin, Martin Rein, Anne-Marie Guillemard, and Herman van Gunsteren. 1991. Time for Retirement. Comparative Studies of Early Exit from the Labor Force. Camebridge University Press.

$\mathrm{KROH}$, Martin. 2009. Documentation of Sample Sizes and Panel attrition in the German Socio Economic Panel (SOEP) (1984 until 2008). Deutsches Institut fuer Wirtschaftsforschung.

LACZKO, Frank, and Chris Phillipson. 1991. "Great Britain: The contradictions of early exit." in Time for Retirement. Comparative Studies of Early Exit from the Labor Force, edited by Martin Kohli, Martin Rein, Anne-Marie Guillemard, and Herman van Gunsteren. Cambridge University Press.

LEISERING, Lutz. 2003. "Government and the Life Course." in Handbook of the Life Course, edited by Jeylan T. Mortimer, and Michael J. Shanahan. Kluwer Academic/Plenum Publishers.

LESNARD, Laurent. 2006. "Optimal Matching and Social Sciences." in CREST-INSEE Working papers. Institut National de la Statistique et des Etudes Economiques.

LESNARD, Laurent.. 2008. "Off-Scheduling within Dual-Earner Couples: An Unequal and Negative Externality for Family Time." American Journal of Sociology 114(2):447-90.

MACINDOE, Heather, and Andrew Abbott. 2004. "Sequence Analysis and Optimal Matching Techniques for Social Science Data." Pp. 387-406 in Handbook of data analysis, edited by Melissa Hardy, and Alan Bryman. Sage Publications.

MARSHALL, Victor W., Philippa J. Clarke, and Peri J. Ballantyne. 2001. "Instability in teh Retirement transition; Effects on health and Well-Being in a Canadian Study." Research on Aging 23:379-409. [doi:10.1177/0164027501234001]

MARTIN, Peter, Ingrid Schoon, and Andy Ross. 2008. "Beyond Transitions: Applying Optimal Matching Analysis to Life Course Research " International Journal of Social Research Methodology 11:179 - 199 [doi:10.1080/13645570701622025]

MAYER, Karl Ulrich. 2005. "Life Courses and Life Chances in a Comparative Perspective." Pp. 17-55 in Analyzing Inequality: Life Chances and Social Mobility in Comparative Perspective, edited by Stefan Svallfors. Stanfrod University Press.

MEYER, Traute, and Birgit Pfau-Effinger. 2006. "Gender Arrangements and Pension Systems in Britain and 
Germany. Tracing change over five decades." International Journal of Ageing and Later Life 1:67-109.

MISCHEL, Walter. 1977. "The Interaction of Person and Situation." in Personality at the Crossroads: Current Issues in Interactional Psychology, edited by David Magnusson, and Norman S. Endler. Lawrence Erlbaum Associates.

MOEN, Phillys, and Patricia V. Roehling. 2005. Career Mystique: Cracks in the American Dream. Rowman \& Littfield.

NEUGART, Michael, and Klaus Schömann (eds.). 2002. Forecasting Labour Markets in OECD Countries: Measuring and Tackling Mismatches. Edward Elgar.

O'RAND, Angela M., and John Henretta. 1999. Age and Inequality. Divers Patterns Through Later Life . Westview Press.

ORLOFF, Ann Shola. 1993. "Gender and the Social Right of Citizenship: The Comparative Analysis of Gender Relations and Welfare States." American Sociological Review 58(3):303-328.

[doi:10.2307/2095903]

RADL, Jonas. 2008. "Too old to work, or too young to retire? Understanding the Structuring of Age Norms in Western Europe." Paper presented at the 1st ISA Forum of Sociology, Barcelona, 5-8 September .

RIPHAHN, Regina T. 1997. "Disability retirement and unemployment - substitute pathways for labour force exit? An empirical test for the case of Germany." Applied Economics 29:551-561. [doi:10.1080/000368497326769]

SCHERER, Stefani. 2001. "Early Career Patterns: A Comparison between Great Britain and West Germany " European Sociological Review 17:119-114. [doi:10.1093/esr/17.2.119]

SCHÖMANN, Klaus. 2006. "The lack of a transitional labour market for older workers in Germany." De Arbeidsmarkt in Vlaanderen. Special Issue 'Active Ageing, Early Retirement and Employability':127-140.

SCHULZE, Isabelle, and Sven Jochem. 2007. "Germany: beyond policy gridlock " in The Handbook of West European Pension Politics, edited by Ellen M. Immergut, and Karen M. Anderson. Oxford University Press.

SCHULZE, Isabelle, and Michael Moran. 2007. "United Kingdom: Pension Politics in an Adversarial System." in The Handbook of West European Pension Politics, edited by Ellen M. Immergut, Karen M. Anderson, and Isabelle Schulze. Oxford University Press.

SZINOVACZ, Maximiliane E. 2003. "Contexts and Pathways: Retirement as Institution, Process, and Experience." Pp. 6-52 in Retirement: Reasons, Processes, and Results, edited by Gary A. Adams, and Terry A. Beehr. Springer.

SZINOVACZ, Maximiliane, David J. Ekerdt, and Barbara H. Vinick (eds.). 1992. Families and Retirement. Sage Publications.

TAYLOR, Marcia, John Brice, Nick Buck, and Elaine Prentice-Lane (eds.). 2007. British Household Panel Survey User Manual Volume A: Introduction, Technical Report and Appendices. University of Essex.

TEIPEN, Christina, and Martin Kohli. 2004. "Early Retirement in Germany." Pp. 93-117 in Ageing and the Transition to Retirement. A Comparative Analysis of European Welfare States, edited by Tony Maltby, Bert de Vroom, Maria Luisa Mirabile, and Einar Overbye. Ashgate.

VAN SOLINGE, Hanna, and Kene Henkens. 2007. "Involuntary Retirement: The Role of Restrictive Circumstances, Timing, and Social Ebeddedness." Journal of Gerontology: SOCIAL SCIENCES 62B(5):S295-S303.

WARD, Joe H. 1963. "Hierarchical Grouping to Optimize an Objective Function." Journal of the American Statistical Association 58(301):236-244. [doi:10.2307/2282967]

WU, Lawrence L. 2000. "Some comments on "Sequence analysis and optimal matching methods in sociology: review and prospect"." Sociological Methods \& Research 29:41-64. [doi:10.1177/0049124100029001003]

\section{Notes}

${ }^{1}$ The analysis focuses on West Germany, the former FRG, exclusively.

${ }^{2}$ SERPS was replaced by the State Second Pension (S2P) in 2002, but for the study cohort primarily SERPS was relevant.

${ }^{3}$ Public preretirement ('Job Release Scheme') is suggested as an additional pathway in Britain. However it was only effective until 1988 and is thus not relevant for the study cohort.

${ }^{4}$ The GSOEP is administered by the German Institute for Economic Research and fielded annually since 1984 (see Haisken-DeNew and Frick 2005). The BHPS is administered at the Institute for Social and Economic Research (ISER) at the University of Essex and fielded annually since 1991 (see Taylor et al. 2007).

${ }^{5}$ The joint occurrence of old age pension and widow pension is most frequent. 7 percent of those who received old age pension simultaneously received widow pension. Income from disability and occupational 
pensions cannot be reconstructed unambiguously in the GSOEP. Since occupational pensions, even though relatively widespread, are of little relevance as the primary source of income in Germany, we consider this a relatively minor problem.

${ }^{6}$ Of those receiving $\mathrm{NI}$ retirement, 37 percent simultaneously receive an occupational pension, 12 percent a private pension. Receiving no income of one's own is not recorded as a separate category in the BHPS.

Time periods in which persons participated in the survey but reported not receiving income from any of the named sources, are coded as receiving no income of their own.

${ }^{7}$ The fact that unemployment and pre-retirement emerge as one pattern demonstrates their similar temporal patterning of pension entrance at age 60 .

${ }^{8} \mathrm{~A}$ subgroup of the German no own income, state pension trajectory remains without an independent source of income until age of 66 , likely due to contracting out-of-state pensions for a 'marriage refund' available upon marriage for women until 1967. 